\title{
Implementation of Safety Standards in Saudi Arabian Scientific Laboratories: An Empirical Study
}

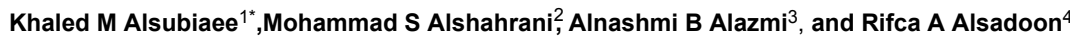

${ }^{1}$ Al Jouf University, Saudi Arabia

${ }^{2}$ Chemical Engineering at KACST, Saudi Arabia

${ }^{3}$ Pharmacy manager at Al haditha hospital, Saudi Arabia

${ }^{4}$ GCC for Entrepreneurship and Innovation, Saudi Arabia

*Corresponding author: Khaled M Alsubiaee, Researcher, Al Jouf University, Saudi Arabia, Tel: +966 558606615; E-mail: Khaledmhd1@hotmail.com

Received date: August 01, 2017; Accepted date: August 22, 2017; Published date: August 24, 2017

Copyright: (c) 2017 Alsubiaee KM, et al. This is an open-access article distributed under the terms of the Creative Commons Attribution License, which permits unrestricted use, distribution, and reproduction in any medium, provided the original author and source are credited.

\begin{abstract}
Background: Implementing safety procedures and precautions minimize the risk of exposure to toxic chemicals and costs of a consequence of a hazardous work environment. Therefore, the aim of this study is to measure the perception of safety standards implementation at different laboratories at the Kingdom of Saudi Arabia.
\end{abstract}

Methods: A cross-sectional study use questionnaire consists of 25 questions. A total of 73 employees, researchers, and students participate in questionnaires distributed in Riyadh, Dammam and Abha cities on 2016, May $10^{\text {th }}$ to June $5^{\text {th }}$.

Results: The majority of participants is male, living in Riyadh, married and has an education higher than secondary school. The age of participants is $28 \pm 5$ years.

Conclusion: The study shows variations in the implementation of security measures and standards at laboratories in three different cities in Saudi Arabia. The Large-scale longitudinal study is recommended for next research.

Keywords: Laboratory; Risk; Chemical Hazards; Safety

\section{Introduction}

The Laboratory is the most precise place where researchers, technicians, and students use to accomplish experiments with various functions: clinical tests, histopathological assessments, toxicological screen, and even for veterinary purposes. Implementing safety procedures and precautions might minimize the risk of exposure to toxic chemicals, and costs of the consequence of a hazardous work environment. Chemical laboratories are dangerous workplaces where they contain enormous hazardous materials. The hazardous substances include flammable, carcinogens, mutagens and radioactive agents. Formerly, several chemical substances used in the laboratories labeled as safe have been recently labeled as dangerous for long-term exposure. A long list of hazardous substances updated regularly with animal experimental research studies such as metal, inorganic compounds, and organic solvents [1]. Such risky substances have negative impacts on workers' health including teratogenic effects on fetal brain development [1].

Various laboratory processes are related to lethal diseases such as nitric oxide synthase as well as carbon monoxide is generating heme oxygen reactions which are associated with Sarcolemma of skeletal muscle fibers receptors of mammalian with unknown molecular mechanism [2].

Four employees were killed and 32 injured in a small chemical business; multi-hundred-gallon reactors known as T2 laboratory, as a result of chemical interaction explosion. The investigations of United States Chemical Safety Board (CSB) revealed that there was uncertainty in the safety process. The CSB suggested that proper recognition of the consequences of a chemical process is a crucial key to determine the risk [3].

In 2010, a student had lost three fingers, burned face and hand, and injured eye at chemistry and biochemistry departments at Texas Tech University. The chemical safety board determined deficiencies in safety measurements as a cause of the accident. The occupational safety hazard was not assessed properly due to the lack of proper incident documentation [4]. Moreover, due to the lack of safety precautions, the undergraduates were at an increased risk of asphyxiation; as a result of working in the Yale University laboratory machine shop in 2011 [5].

European Chemical Agency (ECHA) recommends the use of Safety Data Sheets (SDS) to assure adequate safety information and application of proper precaution of hazardous substances during supply chain, storage, and transportation [6].

A recent study published in the Middle East region, Iraq at AlNahrain University shows that the laboratories never designed based on international standards; almost seven major safety defects emerged within two years post-establishment [7]. Other published studies at the same University, raised the significance of maintenance of the neglected fume cupboard, and the importance of preserving proper ventilation at the undergraduate chemistry laboratories to reduce the accidents $[8,9]$. 
In Saudi Arabia, the safety term is almost always associated with road traffic accidents, [10] hospital infections [11,12] and rarely with the working environment $[13,14]$. In 1998, a survey conducted in Eastern Provence of Saudi Arabia; safety precautions had been found more in large projects as compared to small ones [13]. The aim of this study is to measure the laboratory members' perception of safety standards implementation at different laboratories in the Kingdom of Saudi Arabia.

\section{Methods}

\section{Study design setting and subjects}

A cross-sectional study uses a questionnaire consists of 25 questions adapted from Guidelines for the Development and Application of Health, Safety and Environmental Management Systems [15] American Chemical Society Safety Audit/Inspection Manual and American Chemical Society Security Vulnerability Checklist for Academic and Small Chemical Laboratory Facilities [16].

A pilot study conducted by interviewing 12 participants; shows acceptable Cronbach alpha with moderate internal consistency $(\alpha=0.751>0.7)$ [17]. Based on the accepted range of corrected itemtotal correlations ( 0.30 to 0.70$)$ for a good scale [18] five statements are omitted from the original questionnaire as shown in Table 1.

\begin{tabular}{|l|l|}
\hline Statements & $\begin{array}{l}\text { Corrected Item-Total } \\
\text { Correlation }\end{array}$ \\
\hline Work & 0.197 \\
\hline Safety knowledge & -0.062 \\
\hline Apply safety & 0.183 \\
\hline I think everybody has safety responsibility & 0.023 \\
\hline $\begin{array}{l}\text { There is safeguards techniques applied to insist } \\
\text { lab accidents prevention }\end{array}$ & 0.041 \\
\hline
\end{tabular}

Table1: Corrected item-total correlations for omitted statements.

The questionnaire was modified to have only 20 declarations and questions, among them, five statements are related to demographic data. The other fifteen questions are designed using the Likert scale with five level scale items (strongly agree, agree, neutral, disagree, and strongly disagree). The Arabic translation of questionnaire was validated with expert translators and researchers before and after pilot study.

\section{Data collection}

A total of 100 questionnaires distributed at universities and research centers in Riyadh, Dammam, and Abha cities on 2016, May $10^{\text {th }}$ to June $5^{\text {th }}$. A pilot study conducted by using an interview methodology for 12 participants. The pilot study performed with a sample of researchers, lab technicians, and students at different institutions in Riyadh city.

Additionally, 88 questionnaires distributed in three different cities. Overall, the distributed questionnaires are 40, 30, and 30 in Riyadh, Dammam, and Abha cities respectively. One questionnaire was omitted due to an incomplete answer of questions; the total response rate is $74 \%$.

\section{Statistical analysis plan}

SPSS (IBM Corp. Released 2011. IBM SPSS Statistics for Windows, Version 20.0. Armonk, NY: IBM Corp) was used for data analysis. Based on confidence level $95 \%$, sample size of 100 with a percentage of $50 \%$ chances to participate; the confidence interval is $9.8 \%$. Descriptive analysis used to show the perceptions of safety implementation in laboratories among participants. Demographical data frequency is illustrated in the chart.

\section{Ethical consideration}

All participants were informed with the study objectives and provided answers to their queries. Voluntary participation is collected without their affiliations or names. In the case of participants' queries to receive the final study results, it was sent to them through E-mail.

\section{Results}

Table 2 shows demographic data for participants. The majority of respondents is male, living in Riyadh, married and has an education higher than secondary school. The age of participants is $28 \pm 5$ years.

\begin{tabular}{|c|c|c|c|}
\hline \multicolumn{3}{|c|}{ Demographic data items } & \multirow{2}{*}{$\begin{array}{l}\text { Total } \\
73\end{array}$} \\
\hline \multirow[t]{2}{*}{ sex } & Male & 46 & \\
\hline & Female & 27 & \\
\hline Age & Mean \pm SD & $28 \pm 5$ & 73 \\
\hline \multirow[t]{2}{*}{ Living place } & Riyadh & 37 & \multirow[t]{2}{*}{73} \\
\hline & Out-Riyadh & 36 & \\
\hline \multirow[t]{2}{*}{ Marital status } & Married & 44 & \multirow[t]{2}{*}{73} \\
\hline & Non-Married & 29 & \\
\hline \multirow[t]{2}{*}{ Education } & $\begin{array}{l}\text { Secondary school and } \\
\text { below }\end{array}$ & 7 & \multirow[t]{2}{*}{73} \\
\hline & Above Secondary school & 66 & \\
\hline
\end{tabular}

Table 2: Demographic data.

Figure 1 shows the variety of participants' age distributions.

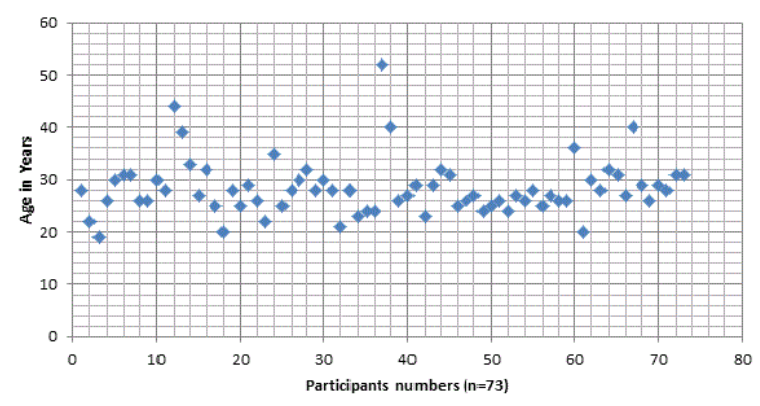

Figure 1: Age distribution among participants.

Table 3 shows contributor's perception for safety implementations. The majority of them agreed that the laboratory has safety policy and procedure written, a presence of the emergency plan, receive required 
safety training, there are labels for identification of substances, and there are control and prediction of risks. Moreover, a high percentage of participants disagree with the availability of the safety evaluation committee, safety violations faced with punishments, and documentation of accidents. Almost $50 \%$ do not agree that there is a commitment to storage requirement. Mostly, the majority are not satisfied with the safety implementations at the laboratory environment.

\begin{tabular}{|c|c|c|c|c|c|}
\hline Statement & $\begin{array}{l}\text { Strongly } \\
\text { disagree }\end{array}$ & Disagree & Neutral & Agree & Strongly Agree \\
\hline There is safety policy and procedure written & 5 & 18 & 12 & 28 & 10 \\
\hline There is emergency plan & 7 & 18 & 14 & 17 & 17 \\
\hline There is safety evaluation committee & 8 & 20 & 10 & 19 & 16 \\
\hline Safety violations faced with punishment & 5 & 18 & 22 & 15 & 13 \\
\hline I received basic training required to deal with danger & 8 & 18 & 14 & 29 & 4 \\
\hline There is lab safety statistical data available & 13 & 13 & 24 & 18 & 5 \\
\hline I document accidents occurs & 13 & 23 & 12 & 19 & 6 \\
\hline There is regular maintenance for lab & 8 & 13 & 27 & 13 & 12 \\
\hline Substances have identification labels and risk information & 2 & 14 & 6 & 33 & 18 \\
\hline There is list for dangerous substances & 8 & 18 & 13 & 16 & 18 \\
\hline There is financial support for safety & 14 & 10 & 23 & 14 & 12 \\
\hline There is safety control and susceptible danger prediction & 15 & 12 & 19 & 16 & 11 \\
\hline There is segregated specific waste containers available & 17 & 16 & 9 & 17 & 14 \\
\hline Storage requirement for chemical substances are met & 6 & 20 & 12 & 22 & 13 \\
\hline Overall, I'm satisfy with safety application in laboratory & 12 & 25 & 12 & 18 & 6 \\
\hline
\end{tabular}

Table 3: Participants' perception towards Safety standards implementation at their institutions.

\section{Discussion}

The concept of safety commitment in laboratories is a fundamental component of shelter against loss. In a cross-sectional study conducted at the Technological Educational Institution of Thessaloniki, Greece, investigates the ability to match hazardous label with a compatible chemical substance. Only $25 \%$ of students enrolled in the questionnaire were able to select the appropriate label to a chemical substance [19]. Almost, in mismatching the labels to correspondent chemical substances, there is no difference between chemistry educated and non-educated students [19]. In this study, the majority of contributors showed agreement towards the safety policy and procedure written, a presence of the emergency plan, basic safety training, availability of substance identification labels, and risks control and prediction. Based on the Theory of Planned Behavior (TPB), the reason might be explained by a behavioral intention to practice security and safety knowledge that construct work environment [20]. However, the gender, state, and grades have no significant difference in safety attitudes [21]. The perception of participants in this study is not designed to measure the safety attitudes among them. To raise safety culture in the organization, a survey showed that the student's safety share is an excellent way to show the importance of safety application and practice in laboratories [22].

A high percentage of participants disagreed towards the availability of the safety evaluation committee, safety violations faced with punishments, and documentation of accidents. Moreover, there is no perception difference regards the commitment to storage requirements between the participants. Overall, the majority are not satisfied with the safety implementations at chosen laboratories.

The major limitation of this study is the cross-sectional design which is weak to determine the causality. Additionally, the limited period of data collection and small sample size weaken generalization of this study. A national survey program on a large scale of laboratories is recommended.

\section{Conflicts of Interests}

The authors declare that they have no conflicts of interests.

\section{Acknowledgements}

We would like to Acknowledge and thank Mrs. Alison Fox, for linguistic revision and recommendations.

\section{References}

1. Grandjean P, Landrigan PJ (2006) Developmental neurotoxicity of industrial chemicals. The Lancet 368: 2167-2178.

2. Feussner M, Richter H, Baum O, Gossrau R (2001) Association of soluble guanylate cyclase with the sarcolemma of mammalian skeletal muscle fibers. Acta histochem 103: 265-277.

3. Theis AE (2014) Case study: T2 Laboratories explosion. J Loss Prev Process Ind 30: 296-300. 
4. Carson P (2014) Texas Tech University laboratory explosion. Loss Prevention Bulletin 238: 12-14.

5. Van Noorden R (2011) Death in the lab. Nature 472: 270-271.

6. Nayar GA, Wehrmeyer W, Phillips CA, Crankshaw N, Marsh N, et al. (2016) The efficacy of Safety Data Sheets in informing risk-based decision making: A review of the aerospace sector. Chem Health Saf 23: 19-29.

7. Ali A, Al-Dahhan W, Zageer D, Yousif E (2017) A Vision to Promote the Forensic DNA Facility at Al-Nahrain University in Terms of Safety Measures. Oriental Journal of Physical Sciences 2: 37-41.

8. Hussein F, Al-Dahhan W, Al-Zuhairi A, Rodda K, Yousif E (2017) Maintenance and Testing of Fume Cupboard. Open Journal of Safety Science and Technology 7: 69-75.

9. Yousif E, Al-Dahhan W, Abed RN (2017) Improvement of a Chemical Storage Room Ventilation System. Pacific Northwest National Lab (PNNL), Richland, WA, United States.

10. Odero W, Garner P, Zwi A (1997) Road traffic injuries in developing countries: a comprehensive review of epidemiological studies. Trop Med Int Health 2: 445-460.

11. Zaki AM, van Boheemen S, Bestebroer TM, Osterhaus ADME, Fouchier RAM (2012) Isolation of a Novel Coronavirus from a Man with Pneumonia in Saudi Arabia. N Engl J Med 367: 1814-1820.

12. Memish ZA, Mah MW (2001) Brucellosis in laboratory workers at a Saudi Arabian hospital. Am J Infect Control 29: 48-52.

13. Jannadi MO, Assaf S (1998) Safety assessment in the built environment of Saudi Arabia. Safety Sci 29: 15-24.
14. Jannadi OA, Bu-Khamsin MS (2002) Safety factors considered by industrial contractors in Saudi Arabia. Build Environ 37: 539-547.

15. Guidelines for the Development and Application of Health, Safety and Environmental Management Systems. Energy and petroleum forum (E\&P forum): London, UK (1994).

16. American Chemical Society (ACS) (Ed.). Safety audit/inspection manual. American Chemical Society: Washington, DC, USA (2000).

17. Nunnaly JC, Bernstein IH (1994) Psychometric theory. McGraw-Hill, Sydney, Australia.

18. Ferketich S (1991) Focus on psychometrics: Aspects of item analysis. Res Nurs Health 14: 165-168.

19. Karapantsios TD, Boutskou EI, Touliopoulou E, Mavros P (2008) Evaluation of chemical laboratory safety based on student comprehension of chemicals labelling. Education for Chemical Engineers 3: e66-e73.

20. Laborda JG, Ozdamli F, Maasoglu Y, Teo TG, Salleh Z (2014) Examining the Potential of Safety Knowledge as Extension Construct for Theory of Planned Behaviour: Explaining Safety Practices of Young Adults at Engineering Laboratories and Workshops. Procedia Soc Behav Sci 116: 1513-1518.

21. Can Ş, Aksay EÇ, Orhan TY (2015) Investigation of Pre-service Science Teachers' Attitudes towards Laboratory Safety. Procedia Soc Behav Sci 174: 3131-3136.

22. Shallcross DC (2014) Safety shares in the chemical engineering classroom. Education for Chemical Engineers 9: e94-e105. 